IZA DP No. 717

International Fragmentation and

Relative Wages in the UK

Alexander Hijzen

Holger Görg

Robert C. Hine

February 2003 


\title{
International Fragmentation and Relative Wages in the UK
}

\author{
Alexander Hijzen \\ University of Nottingham \\ Holger Görg \\ University of Nottingham and IZA Bonn \\ Robert C. Hine \\ University of Nottingham \\ Discussion Paper No. 717 \\ February 2003
}

\author{
IZA \\ P.O. Box 7240 \\ D-53072 Bonn \\ Germany \\ Tel.: +49-228-3894-0 \\ Fax: +49-228-3894-210 \\ Email: iza@iza.org
}

This Discussion Paper is issued within the framework of IZA's research area Internationalization of Labor Markets. Any opinions expressed here are those of the author(s) and not those of the institute. Research disseminated by IZA may include views on policy, but the institute itself takes no institutional policy positions.

The Institute for the Study of Labor (IZA) in Bonn is a local and virtual international research center and a place of communication between science, politics and business. IZA is an independent, nonprofit limited liability company (Gesellschaft mit beschränkter Haftung) supported by the Deutsche Post AG. The center is associated with the University of Bonn and offers a stimulating research environment through its research networks, research support, and visitors and doctoral programs. IZA engages in (i) original and internationally competitive research in all fields of labor economics, (ii) development of policy concepts, and (iii) dissemination of research results and concepts to the interested public. The current research program deals with (1) mobility and flexibility of labor, (2) internationalization of labor markets, (3) welfare state and labor market, (4) labor markets in transition countries, (5) the future of labor, (6) evaluation of labor market policies and projects and (7) general labor economics.

IZA Discussion Papers often represent preliminary work and are circulated to encourage discussion. Citation of such a paper should account for its provisional character. A revised version may be available on the IZA website (www.iza.org) or directly from the author. 
IZA Discussion Paper No. 717

February 2003

\section{ABSTRACT}

\section{International Fragmentation and Relative Wages in the UK}

This paper re-examines the trade-based explanation of increased wage inequality in developed countries by focusing on international outsourcing. It is the first detailed study to address the effects of outsourcing on labour markets in the UK. In a recent paper, Feenstra and Hanson (1996) estimate the effect of international outsourcing on wage inequality in the US. This paper extends the FH approach by using more detailed definitions of outsourcing and skill. The analysis applies to UK manufacturing over the period 1982-1997. Extending the analysis to the 1990s is considered to be crucial as outsourcing is predominantly a phenomenon of the 1990s. The econometric results suggest that technical change, import penetration and outsourcing all play an important role in explaining UK wage inequality. Outsourcing may account for about half of the increase in domestic wage inequality.

JEL Classification: F14, J31

Keywords: fragmentation, outsourcing, trade, wages, skill-biased technological change

Corresponding author:

Holger Görg

School of Economics

University of Nottingham

Nottingham NG7 2RD

UK

Tel.: +44115846 6393

Fax: +441159514159

Email: holger.gorg@nottingham.ac.uk

\footnotetext{
${ }^{*}$ Financial support from the European Commission Fifth Framework Programme (Contract No. HPSECT-1999-00017) and the Leverhulme Trust (Programme Grant F114/BF) is gratefully acknowledged. The authors wish to thank Richard Upward for the provision of the NES data and David Greenaway and Doug Nelson for helpful comments and suggestions. All remaining errors are, of course, the authors'.
} 


\section{Introduction}

One of the main consequences of the process of globalisation is the increasing international fragmentation of production. ${ }^{1}$ This phenomenon is likely to have important implications for both the composition and the pattern of international trade.

International fragmentation of production leads to the establishment of international production networks, which are associated with trade in intermediates. Some recent studies have provided evidence of the growing importance of trade in intermediates (Campa and Goldberg, 1997; Yeats, 2001). From the data for the UK used in this paper it follows that total outsourcing in terms of value-added increase from $38 \%$ in 1984 to $53 \%$ in 1995 , while outsourcing within the same industry increased from $11 \%$ to $16 \%$ over the same period.

However, fragmentation does not only affect the composition of international trade but may also change the pattern of trade. In the literature on fragmentation the main driving force behind outsourcing is the existence of differences in factor prices across national borders. Unskilled labour-intensive stages of production tend to be shifted to unskilled labour-abundant developing countries, while more technologically advanced stages remain in skilled labour-abundant developed countries. As a result the increasing international fragmentation of production enhances the integration of developing countries in the world economy. Indeed for the UK the share of imports from developing countries over total imports increased from $18 \%$ to $22 \%$ over the period 1982-1996 indicating increased competition from low-wage countries.

It is, therefore, worth analysing the impact of fragmentation on labour markets and in particular on the skill structure of demand. Many have expressed the fear in developed countries that outsourcing will tend to reduce the demand for unskilled workers resulting in either falling relative wages or increased unskilled unemployment. However, from the theoretical literature it follows that this is not necessarily the case. Moreover, it is an empirical question whether outsourcing is a sufficiently large phenomenon in order to account for significant labour market effects.

This paper relates fragmentation to wage inequality as there still does not exist a consensus on the predominant source of the trend in wage inequality. Some argue that skill-biased technological change is responsible for the shift in the relative demand of skilled workers, others hold increased import competition from low-wage countries reducing employment for the unskilled responsible for the growing income divide within countries. Most empirical work indicates that technological change explains the lion's share of the increase in wage inequality, although trade appears to play a significant role as well.

\footnotetext{
${ }^{1}$ The term fragmentation was coined by Jones and Kierzkowski (1990). It refers to the splitting up of production processes into separate components so that they can be produced in different locations. There exist many terms that are used to indicate the same phenomenon. These are amongst others, vertical specialisation (Hummels, Ishii and Yi, 2001), intra-product specialisation (Arndt, 1997), delocalization (Leamer, 1998), outsourcing (Feenstra and Hanson), disintegration (Feenstra, 1998). Throughout this paper these terms will be used interchangeably.
} 
The purpose of this paper is to re-examine the trade-based explanation by focusing on international outsourcing in UK manufacturing. Outsourcing differs importantly from import penetration in final goods in the sense that it explicitly takes into account the extent to which firms move production activities abroad. Moreover, labour demand is not only affected in import-competing industries, but in all industries that use foreign inputs. Hence, the impact of outsourcing may not be limited to changing labour demands between industries, but also affects the relative demand for labour within industries.

In a recent paper, Feenstra and Hanson (1996) estimate the effect of international outsourcing on wage inequality in the US using a partial-equilibrium approach based on a translog cost function. They measure outsourcing (fragmentation) as the share of imported intermediate inputs in total intermediate inputs using input-output data from the Census of Manufactures and trade data from the NBER trade data base. They find that outsourcing had a strong positive effect on the relative wage of skilled workers in the US over the period 1979-1990.

The present paper is the first detailed study of the effects of outsourcing for the UK. ${ }^{2}$ It aims at applying and extending the Feenstra and Hanson approach by using inputoutput data for 53 manufacturing industries for the period 1982-1997. By using the import-use matrices of the input-output tables instead of total intermediate purchases the measure of outsourcing employed in this paper can be deemed more appropriate than the measure used by Feenstra and Hanson. The inclusion of the 1990s in the analysis is thought to be a crucial part of the contribution of this paper as international fragmentation seems to be predominantly a phenomenon of the last decade. Finally, labour market data, obtained from the New Earnings Survey (NES), allow one to define skill groups on the basis of the Standard Occupational Classification (SOC) instead of the crude distinction between manual and non-manual workers used elsewhere in the literature.

The paper is structured as follows. Section 2 presents a brief discussion on the theory on fragmentation in relation with relative wages. The emphasis is put on the discussion of sector bias versus factor bias. Section 3 gives a selective survey of the empirical literature. Section 4 presents descriptive data on labour market developments and fragmentation. A first attempt will be made to link the two phenomena. Section 5 sets out the methodology employed in the econometric analysis and Section 6 contains the results. Finally, Section 7 concludes.

\section{Theory}

The two main demand-side explanations of the increase in domestic wage inequality have focused on the role of skill-biased technological change (SBTC) and international trade. Until recently skill-biased technological change was associated with within-industry changes in skill intensity as a result of its effect on the relative productivity of different skill groups (factor bias), whereas international trade was

\footnotetext{
2 Anderton and Brenton (1999) focus on outsourcing, but do not explicitly measure outsourcing. Machin and Van Reenen (1998), Haskel and Heden (1999) and Haskel and Slaughter (2001) aim at explaining the increase in UK wage inequality but do not consider the role of outsourcing.
} 
associated with between-industry changes based on general equilibrium trade models (sector bias). If the factor bias matters the analysis should concentrate on the skillintensity of the activity moved abroad relative to the remaining activities in that industry, whereas if one believes the sector bias is important one should focus the relative cost-saving effect of outsourcing across sectors. Empirically these two explanations were therefore investigated using different methodologies. Relative labour demand regressions were mainly used to estimate the impact of SBTC, whereas trade economists generally favoured product price studies. ${ }^{3}$

Recently, however, it has become increasingly apparent that this is too simple a way of representing reality. First, Feenstra and Hanson (1995) re-examine the trade-based explanation by focussing on the impact of outsourcing, that is trade in intermediates. They argue that outsourcing has a qualitatively similar impact as SBTC and therefore emphasise the factor bias. "In fact, the whole distinction between 'trade' versus 'technology' becomes suspect when we think of corporations shifting activities overseas (Feenstra, 1998, p. 41)". Second, Haskel and Slaughter (2001) have pointed out that even skill-neutral technological change can account for some of the increase in relative wages emphasising the sector bias of technological change. As long as technical change affects the relative profitability of sectors can it affect relative factor prices (Haskel, 2000).

The theoretical literature on fragmentation or outsourcing generally takes the form of moving unskilled intensive manufacturing processes from a developed country to a developing country. It is argued that fragmentation has a similar effect as technological change. However, the question whether one should emphasise the factor or the sector bias of outsourcing in order to analyse its impact on domestic wage inequality is open to debate as will become clear from the following discussion. ${ }^{4}$

Feenstra and Hanson (1995), Kohler (2001), and Deardorff (2001) present very different models of outsourcing. However, they all show that the factor intensity of the component moved abroad may matter. As such they provide each in their own way a justification for using a partial equilibrium approach in the empirical analysis of outsourcing thereby emphasising the factor bias.

Feenstra and Hanson (1995) model outsourcing of unskilled-intensive fragments from the US to Mexico in order to explain the empirical finding of increasing wage inequality in both the US and Mexico. They do so by analysing outsourcing in a onesector two-country framework with capital mobility. They argue that outsourcing has a qualitatively similar effect as SBTC and as a result emphasise the factor bias of outsourcing. Krugman (2000) points out that technological change at home and abroad has a similar effect as technological change in a closed economy. As in a closed economy the factor bias of technological change determines what happens to relative factor prices, it is also justified to emphasise the factor bias of outsourcing when outsourcing induces upgrading at home and abroad.

\footnotetext{
${ }^{3}$ See Chennels and Van Reenen (1999) for a survey of the former and Slaughter (2000) and Haskel (2000) for surveys of the latter literature.

${ }^{4}$ Hijzen (2002) tries to gain more insight in this issue by empirically estimating the sector and factor bias of outsourcing and SBTC in a common framework.
} 
Kohler (2001) discusses the possibility of outsourcing in a specific-factors model where capital is immobile across sectors, but may be mobile across national borders (foreign direct investment), while labour is mobile across sectors. With foreign direct investment outsourcing of any component reduces the domestic real wage. Without foreign direct investment -capital and labour are supplied perfectly elastically abroad so that domestic firms face a given a unit price for foreign components- the impact of outsourcing on real wages depends crucially on the factor-intensity of the activity moved abroad. Only in the case that the activity is relatively labour-intensive will outsourcing reduce real wages. Thus, in the case of outsourcing in a specific-factors model without international capital mobility the factor bias matters.

Deardorff (2001) analyses fragmentation across cones, i.e. in the absence of factor price equalisation. He argues that the impact of fragmentation on relative factor prices depends crucially on the relative factor-intensity of the fragment being moved abroad and the average factor intensity in the economy. The result is driven by the assumption of completely specialised economies inspired by the fact that it is the absence of factor price equalisation that drives outsourcing. Deardorff also notes that in an economy with many industries and fragmentation being possible only in some of them, its impact on relative factor prices is greatly reduced in comparison to the simple $2 \times 2$ case.

Finally it is worth mentioning Arndt (1997) who analyses the impact of fragmentation in a small open developed economy in a standard $2 \times 2 \times 2$ Heckscher-Ohlin model. Consequently, Arndt emphasises the sector bias of outsourcing. He concludes that outsourcing of labour-intensive components in the labour-intensive industry actually reduces wage inequality whereas outsourcing of labour-intensive components in the capital/skill-intensive industry increases wage inequality. The difference with Deardorff resides in the fact that Deardorff considers a completely specialised economy, while Arndt considers an open-diversified economy. Consequently, in the analysis conducted by Arndt only the sector bias matters. Jones and Kierzkowski (2001) confirm these possibilities, but also stress the radical nature of outsourcing for which the Heckscher-Ohlin framework may be ill equipped. A priori, therefore, it is very difficult to predict how fragmentation will actually affect relative wages.

The present study approaches outsourcing from a one-sector perspective by estimating the relative demand for labour. Outsourcing of labour-intensive components abroad is expected to reinforce wage inequality. If outsourcing turns out insignificant or negative this may be either due to the limited magnitude of the phenomenon or outsourcing may be driven to an important extent by other considerations than labour cost differentials.

\section{Empirical Literature}

The empirical literature analysing the impact of international fragmentation of production on domestic wage inequality is still fairly limited. Feenstra and Hanson $(1995,1996)$ are the first to approach the question of wage inequality from the angle of outsourcing. They adopt the methodology advanced by Berman et al. (1994) who proposed to estimate relative labour demands in order to analyse the factors driving the widening wage gap in the US. Feenstra and Hanson measure outsourcing by 
combining disaggregated data on total intermediate purchases obtained from the Census of Manufacturers with trade statistics and add their measure of outsourcing (or import penetration) to a translog cost function.

Feenstra and Hanson use data for the period 1972-1990. The regression analysis only provides evidence for a positive effect of outsourcing on the relative demand for labour for the 1980s. Over this period outsourcing accounted for about $30 \%$ to $50 \%$ of the increase in the nonproduction wage share, which is considerably more than the proportion explained by the import penetration variable. They argue that this is because outsourcing directly measures the extent to which industries move production to low-wage countries. A possible explanation for the lack of evidence for the 1970s and the convincing evidence for the 1980s is sought in a change in the pattern of trade resulting from the increasing relative importance of developing countries in world trade.

In Feenstra and Hanson (1999) the measure of outsourcing is refined by distinguishing between narrow and broad outsourcing. 5 The broad definition of international outsourcing captures all imported intermediates within a given industry, that is

$$
S_{O}^{B}=\frac{\sum_{i=1}^{i} O_{i j t}}{V A_{j t}}
$$

The narrow definition of international outsourcing only considers imported intermediates in a given industry from the same industry (which corresponds to diagonal terms of the import-use matrix), i.e.,

$$
S_{O}^{N}=\frac{O_{i=j, t}}{V A_{j t}}
$$

The broad definition (which corresponds to the column totals of the import-use matrix) was used in their earlier work. The narrow definition is preferred by Feenstra and Hanson as it is thought to come closer to the real idea of outsourcing (it excludes packaging or primary inputs such as steel, for example) especially when the level of aggregation is relatively high (2-digit). From the empirical analysis it follows that narrow outsourcing is indeed more important in explaining changes in the cost shares indicating that it is a more precise measure of outsourcing. Outsourcing accounts for $13-23 \%$ of the variation, while technology for about $8-32 \%$ depending on the proxy used. ${ }^{6}$ They conclude that both outsourcing and SBTC are important.

Anderton and Brenton (1999) analyse the impact of outsourcing on wage inequality in the UK by estimating the impact of total imports on relative wages in the textiles and

\footnotetext{
${ }^{5}$ Note that the formal representations are based on the use of import-use matrices (not as in Feenstra and Hanson, 1997, 1999).

${ }^{6}$ Feenstra and Hanson $(1997,1999)$ actually try to integrate the two main explanations by using a general equilibrium approach estimating so-called mandated wage regressions. In order to make their results comparable to previous results they re-run the standard regression with the new data. These are the regressions referred to in the text.
} 
non-electrical machinery industries for the period 1970-1983. They distinguish import penetration from developed and from developing countries; however, they do not consider trade in intermediates, which constitutes the essence of outsourcing but focus on total imports.

Dell'mour et al. (2000) analyse the impact of outsourcing on labour markets using input-output data for the case of Austria over the period 1990-1998. As wages are assumed to be fairly rigid in Austria the employment share of skilled workers is used as the dependent variable in the relative labour demand regressions. For their measure of outsourcing they account for the origin of imports by multiplying imported intermediates by the share of a region's imports over total imports.

\section{Trends in Labour Markets and Fragmentation}

In this section the data on labour markets and fragmentation will be discussed and the developments over the period 1982-1997 analysed. A first attempt will be made to link the two developments together before going to the actual regression stage.

\subsection{Labour markets (1982-1997)}

In most developed countries it is a well-established fact that the demand for skilled labour has risen relative to that for unskilled labour. As a result in countries with flexible labour markets the wage gap between the unskilled and the skilled has increased significantly over the last few decades. In countries with relatively rigid labour markets the change in relative demand may be reflected in changes in relative employment/unemployment.

Labour market data are obtained from the New Earnings Survey (NES). The NES is based on a series of surveys that cover approximately one percent of the working population. Besides providing data on wages, employment and numerous other factors, it also classifies each employee to the Standard Occupational Classification (SOC), which allows one to construct a more accurate measure of skill than the one based on manual/non-manual workers generally used in the literature (Feenstra and Hanson, 1996; Machin and Van Reenen, 1998). In the NES workers are classified according to 9 Major Groups and 22 Sub-Major Groups. ${ }^{7}$ The SOC Major Groups are based on qualifications, training, skills, and experience, while the Sub-Major Groups are determined by the nature of the job. Therefore, distinguishing skill groups on the basis of their Major Group Codes allows one to construct a very accurate measure of skill. For the determination of skill groups the approach taken by Gregory, Zissimos and Greenhalgh (2001) is adopted. Apart from providing a more accurate measure of skill, this approach allows one to distinguish three skill groups: skilled, intermediate, and unskilled. ${ }^{8}$ As a result it is possible to see to what extent wage inequality is a phenomenon of the tails or instead affects the whole labour force. Finally, the present study is limited to male workers.

\footnotetext{
${ }^{7}$ For a description of those skill groups see the appendix to this section.

${ }^{8}$ Unskilled workers are those classified in Major Groups 1 to 3, semi-skilled workers in Major Groups 4 to 7 , and skilled workers in Major Groups in 8 and 9.
} 
Table 1 shows relative wage developments between different skill groups based on the average hourly wages of each skill group. Generally the table indicates an increase in the relative wage in favour of skilled labour. A closer look reveals that relative wage of the semi-skilled to the unskilled has been relatively stable over time. The relative wage of skilled workers to both semi-skilled and unskilled workers has risen significantly. Therefore, it seems reasonable to group unskilled and semi-skilled workers together. Thus, in the following the unskilled category includes both semiskilled and unskilled workers.

Inspection of the data on relative employment developments between skill groups (not reported here) shows that absolute employment dropped importantly in all three categories indicating the increased importance of services relative to manufacturing. Total skilled labour fell by $23 \%$, semi-skilled employment by $29 \%$, and unskilled employment by $19 \%$. Relative employment, however, remained fairly constant for all skill pairs with only the share of semi-skilled labour to unskilled labour falling slightly.

Gregory et al. (2001) analyse the changes in the skill structure of labour demand for the whole economy including services. Their analysis is particularly interesting as they use the same labour market data and the same criterion to distinguish skill. Their findings therefore complement the results in this paper. They show that the share of skilled labour increased from $25 \%$ to $31 \%$ over the period $1979-1990$, while the share of semi-skilled labour fell slightly from $48 \%$ to $47 \%$ and unskilled employment dropped from $25 \%$ to $21 \%$.

Figure 1a represents the share of the wage bill spent on skilled labour. The figure confirms the widely documented increase in domestic wage inequality during the 1980s and early 1990s. The graph indicates a sharp fall in the skilled cost share of the wage bill from 1993 onwards. This however should be interpreted with caution as the 1998 value not presented shows that the skilled labour cost share is back on its 1993 level. ${ }^{9}$ Therefore, instead of observing a reversal of the trend it would be more appropriate to speak of the 'levelling off' of the trend in line with evidence for the US (Autor, Katz and Krueger, 1998).

\section{[Figures $1 \mathrm{a}$ and $1 \mathrm{~b}$ here]}

Figure $1 \mathrm{~b}$ represents the employment share of skilled labour over total manufacturing employment. The figure indicates broadly the same trend as Figure $1 \mathrm{a} .{ }^{10}$

\subsection{Fragmentation}

\footnotetext{
${ }^{9}$ The 1998 observation was omitted due to data limitations for other variables.

${ }^{10}$ It should be noted that the share of unskilled employment follows quite a similar path (whereas one would expect the opposite). Both types of labour therefore gain in importance relative to semi-skilled labour.
} 
The increasing international fragmentation of production translates into the rising importance of trade in intermediate products (Feenstra, 1998). Recently, several studies have attempted to shed light on the development of trade in intermediates using diverse data sources.

Yeats (2001) uses SITC Rev.3 trade statistics in combination with outward processing trade data (OPT) and finds that trade in intermediates accounts for approximately $30 \%$ of total trade in the US. He does, however, note that this figure may be much higher for developing countries as those countries are more and more the focus of outsourcing from developed countries.

Görg (2000), using Eurostat data on inward processing trade (IPT) for EU countries, shows that IPT in the 'peripheral' countries of the EU increased from 12 to $24 \%$ of imports from the US. Egger and Egger (2001) find that outward processing in EU manufacturing increased by $6 \%$ per year for the period 1995-1997. They show that outward processing is biased towards import-competing industries, which correspond broadly to the unskilled-intensive industries. Baldone et al. (2001) use OPT data to analyse economic integration in the textiles and apparel industry between the EU and the CEECs. They find that although low wages drive the initial decision to delocalise production activities, cultural ties and geographical proximity determine which CEEC is eventually chosen.

Campa and Goldberg (1997) using data derived from input-output tables for four OECD countries observe that the ratio of imported intermediates to sales in UK manufacturing rose from $13 \%$ in 1974 to $22 \%$ in 1993 , while import penetration rose from approximately 20 to $30 \%$ over the same period. ${ }^{11}$ Hummels, Ishii and Yi (2001) analyse input-output tables for 10 OECD and four emerging market economies and find that outsourcing accounts, on average, for about $20 \%$ of exports from these countries.

Input-output tables are the most appropriate source to analyse simultaneously developments across industries and time. Hence, in this study outsourcing will be measured with the help of input-output tables. There are at least two limitations to the use of these data for the analysis of fragmentation. First, when focusing on trade in intermediates one necessarily ignores the possibility of outsourcing of the final production stage such as assembly ( $\mathrm{Ng}$ and Yeats, 1999). Second, the data do not capture outsourcing when products are not re-imported, but exported to third markets.

For the UK approximately every five years input-output tables are developed that distinguish between imported intermediates and domestically produced intermediates (import-use and domestic-use matrix). The present study uses input-output tables for 1984, 1990 and 1995. In addition, from 1992 onwards combined-use matrices are available annually.

In Feenstra and Hanson (1996) outsourcing is defined as the change in the combineduse matrix times the change in the import penetration shares within that industry

\footnotetext{
${ }^{11}$ Campa and Goldberg (1997) note that imported intermediates tend to be high in sectors where import penetration ratios are high leading to the conclusion that outsourcing occurs within the same broad industry.
} 
divided by the change in total intermediate purchases. Compared to Feentra and Hanson (1996) using import-use matrices instead of combined-used matrices plus trade data has the advantage that outsourcing is no longer driven by increased import penetration of all goods. Increased import penetration refers both to trade in intermediates and trade in final goods. A measure of outsourcing defined as trade in intermediates may therefore be biased when final goods are included, i.e. the significance of outsourcing may be underestimated when trade in intermediates grows faster than trade in final goods.

Following Feenstra and Hanson (1999) both the narrow and broad outsourcing are adopted as both measures are subject to different short-comings. From a theoretical perspective broad outsourcing measuring trade in intermediates by purchasing industry, may be inappropriate for the analysis of fragmentation as it does not focus on intra-product specialisation which is likely to take place within the industry. In addition, the distinction between narrow and broad outsourcing as introduced by Feenstra and Hanson (1999) is very crude as it is purely based on the way industries are classified. From a fragmentation perspective it can well be the case that industries are classified on an unequal level of disaggregation. Compare for example the two following industries: 'motor vehicles and parts' and 'textiles'. Both industries are classical examples where fragmentation occurs. However, 'automobiles and parts' is represented in the input-output tables for the UK as one single industry, whereas textiles are made up of 10 different industries. As a result the narrow measure of outsourcing will not pick up much of the outsourcing in textiles. The broad measure on the other hand will be distorted through the inclusion of raw materials.

One may refine the outsourcing variable to outsourcing to low-wage countries (Anderton and Brenton, 1999; Dell'mour et al, 2000). Developed countries can be defined as those countries that are members of the OECD, and developing countries the rest of the world. The measure of outsourcing is multiplied by the import share of the UK from developing countries over total imports. Thereby emphasis is given to the observation that trade in intermediates is especially important in trade with developing countries. Thus for narrow outsourcing this gives: ${ }^{12}$

$S_{O}^{N}=\frac{O_{i=j, t}}{V A_{j t}} * \frac{M_{j l d c}}{M_{j}}$

Total international outsourcing in terms of value added increased from $37.7 \%$ in 1984 to $40.2 \%$ in 1990 and to $53.4 \%$ in 1995 , while narrow outsourcing increased remained constant during the $1980 \mathrm{~s}$ at $11.1 \%$ and increased to $16.3 \%$ in 1995 . It follows that outsourcing is indeed predominantly a phenomenon of the 1990s. For comparison total domestic and international outsourcing increased from $103.7 \%$ to $182.4 \%$ over the period 1984-1997, while narrow domestic and international outsourcing increased from $32.5 \%$ to $39.6 \%$. The data signal a trend by firms to concentrate more on core activities.

\footnotetext{
${ }^{12}$ For convenience of the calculation of the broad measure of outsourcing it is assumed that the share of imported intermediates from developing countries over total imports is constant across input selling sectors, i.e. equals the share in the purchasing industry.
} 
The sectoral analysis of outsourcing shows that there exists substantial variation across industries. Three industries that exhibit very high broad outsourcing are 'basic non-ferrous metals', 'electronic consumer goods, records and tapes', and 'grain milling, starch, and food products'. That it is important to define outsourcing carefully becomes clear when comparing narrow and broad outsourcing. Only 'basic nonferrous metals' and 'oils and fats' show significant outsourcing under the narrow definition. It seems that the narrow definition is too strict a measure of outsourcing as electronics is one of those industries that inspired the debate on fragmentation.

In order to get a first impression about the relationship between fragmentation and wage inequality, it is illuminating to relate fragmentation to skill intensity. If there exists a negative relation indicating that fragmentation is driven by factor cost differences, outsourcing may be an important factor in explaining domestic wage inequality. Industries within the same range of skill intensity are grouped together in clusters. Skill intensity is measured as the cost share of skilled labour over the total wage bill. ${ }^{13}$ Figure 2 shows broad and narrow outsourcing for 1984, 1990, and 1995 across three clusters of skill intensity with skill-intensity increasing from left to right. ${ }^{14}$ Figure 2 a seems to suggest a negative relationship between broad outsourcing and skill intensity for the 1980s implying that unskilled-intensive industries may be more prone to outsourcing, however in the 1990s outsourcing was no longer subject to $\mathrm{a}$ clear sector-bias. Figure $2 \mathrm{~b}$ indicates a negative a relation between narrow outsourcing and skill intensity in 1984, no apparent relation in 1990 and a positive relation in $1995 .^{15}$

The trend in the data is actually consistent with the business literature on outsourcing that asserts that initially outsourcing was mainly cost-driven, however when firms acquire more experience in outsourcing strategic motivations such as focusing on core activities (economies of scale) and product development become more important. (Corbett \& Associates, 1999). The main question remains though. Even when one is able to highlight the sector-bias of outsourcing it will be very hard to say anything about the factor-intensity of the outsourced component relative to the remaining components.

\section{[Figures $2 a$ and $2 b$ here]}

\section{Econometric Analysis}

In order to estimate the effect of outsourcing, import penetration and technology on relative wages in UK manufacturing we take a translog cost function approach. This methodology, which by now has become standard in the literature, is based on the

\footnotetext{
${ }^{13}$ This is also the dependent variable that will be used in the regression analysis.

${ }^{14}$ Skill-intensity clusters are based on the averages over the entire sample period. One might argue that outsourcing has significant effects on skill-intensity (Egger and Egger, 2001) and therefore it would be more appropriate to relate the level of outsourcing to the skill-intensity at that time. However, it turned out that this does not change the picture.

${ }^{15}$ However, it should be noted these figures are not appropriate to analyse the impact of outsourcing on skill upgrading as one cannot control for any other exogenous factors that may affect skill intensity. To do so, one needs to estimate a properly specified econometric model.
} 
work of Berman, Bound and Griliches (1994) and Feenstra and Hanson (1996). ${ }^{16}$ The translog cost function has the useful property that its first derivatives with respect to factor returns gives the factor cost shares. Following Berman et al. capital is quasifixed so that both output and capital can be treated as fixed in the short-run, while skilled and unskilled labour are the only variable factors of production. ${ }^{17}$ In general notation the translog cost function can be represented as follows:

$$
\begin{aligned}
\ln C_{i}=\alpha_{o}+\sum_{j=1}^{J} \alpha_{j} & \ln w_{i j}+\sum_{k=1}^{K} \beta_{k} \ln x_{i k}+\frac{1}{2} \sum_{j=1}^{J} \sum_{s=1}^{J} \gamma_{j s} \ln w_{i j} \ln w_{i s} \\
& +\frac{1}{2} \sum_{k=1}^{K} \sum_{l=1}^{K} \delta_{k l} \ln x_{i k} \ln x_{i l}+\sum_{j=1}^{J} \sum_{k=1}^{K} \varphi_{j k} \ln w_{i j} \ln x_{i k}
\end{aligned}
$$

where $C_{i}$ is the variable cost for industry $i=1, \ldots, I, w_{i j}$ denotes wages of the optimal skill-mix of workers for skill group $j=1, \ldots, J$, and $x_{i k}$ denotes fixed inputs or outputs $k=1, \ldots, K$.

Differentiating the translog cost function with respect to wages yields the factor payments to skill group $j$ over the total wage bill.

$$
S_{i j}=\alpha_{j}+\sum_{s=1}^{J} \gamma_{j s} \ln w_{i j}+\sum_{k=1}^{K} \varphi_{j k} \ln x_{i k}, j=1, . ., s, ., J
$$

Most studies using this approach have estimated this set of equations by pooling data across industries thereby assuming that the same cost function applies across industries (e.g. Berman et al., 1994; Feentra and Hanson, 1996). Berman et al. argue that the cross-industry variation of wages reflects only differences in the quality of workers and thus assume that quality-adjusted wages will be constant across industries. Therefore, the wage terms can be dropped from the right-hand-side of the equation above. ${ }^{18}$

$$
S_{i j}=\alpha_{j}+\sum_{k=1}^{K} \varphi_{j k} \ln x_{i k}, j=1, \ldots, J
$$

Feenstra and Hanson (2001) argue that one should include "any structural variables that shift the production function and therefore affect costs (p. 21)". The structural variables include import penetration, outsourcing and technological change. ${ }^{19}$ A full set of time dummies is included in order to capture developments in the economy's

\footnotetext{
${ }^{16}$ As pointed out above, this approach is a partial equilibrium approach. An alternative approach would be to investigate general equilibrium effects estimating mandated wage regressions (see Slaughter, 2000). While this is beyond the scope of the present paper it is a topic for further research.

${ }^{17}$ As pointed out above, semi-skilled and unskilled workers are grouped together. If one were to maintain three variable inputs, one would have to estimate a system of two equations further complicating the translog cost function.

${ }^{18}$ Dropping relative wages also solves the problems of endogeneity and collinearity with the dependent variable.

19 According to the Stolper-Samuelson theorem relative labour demand is simply determined by relative goods prices. However, Feenstra and Hanson (1996) argue that outsourcing has an impact on unit input requirements which is related to changes in relative commodity prices in a large country. The regressions, therefore, can be seen as a reduced-form relationship between outsourcing and the unit input requirement for skilled labour.
} 
skill preferences over time. Writing in full and including the structural variables gives the following equation:

$$
S_{i j}=\varphi_{j 0}+\varphi_{j 1} \ln K_{i}+\varphi_{j 2} \ln Y_{i}+\varphi_{j 3} T_{i}+\varphi_{j 4} M_{i}+\varphi_{j 5} O_{i}+\varphi_{j 6} D+\varepsilon_{i}
$$

where $K$ denotes capital intensity measured by capital stock in industry $i$ over sales, $Y$ output in industry $i$ measured by sales, $T$ is a proxy for technological change calculated as expenditure on R\&D over value-added, $M$ represents import penetration measured both in terms of total imports, imports from developed countries and imports from developing countries, $O$ reflects either broad or narrow outsourcing and $D$ is a full set of time dummies. In order to emphasise outsourcing of low skilledintensive activities the two measures of outsourcing multiplied by the share of developing countries imports over total imports.

Most studies take first differences in order to purge industry-specific time-invariant effects. The present study instead applies panel data estimation techniques to estimate equation (4) rather than first differences. There are at least two reasons for doing so. First, it is well known that first-differencing exacerbates potential problems of measurement error in the data (see Griliches and Hausman, 1986). Second, firstdifferencing only allows one to look at the changes in the variables, whereas panel estimation uses levels of the variables. The model is estimated using fixed effects techniques given that the cross-sectional units are a constant set of manufacturing sectors.

\section{Results}

This section presents the results of the regression analysis. It has become common practice in the literature to weight regressions in order to account for differences in industry size (see, for example, Baldwin and Cain, 2000). The variables in all regressions are, therefore, pre-multiplied by the share of average sector value added over average manufacturing value added.

Table 2 contains the results of the fixed-effects estimations of the cost shares of skilled labour over the total wage bill over the period 1982-1997. In regression (1) SBTC is evaluated together with capital intensity and output. Capital intensity and output are positive and statistically significant. The positive sign on capital intensity confirms the idea that capital and skill are complements. ${ }^{20} \mathrm{R} \& \mathrm{D}$ is positive and significant which is taken of evidence for an important role of SBTC in explaining the increase in wage inequality.

\section{[Table 2 here]}

Regressions (2)-(4) include three different measures of foreign competition in the regression. M1 reflects total import penetration, M2 import penetration from developing countries and M3 import penetration from developed countries. Anderton

\footnotetext{
${ }^{20}$ Experiments excluding sales or replacing capital intensity by capital stock did not change results significantly for the variables of interest.
} 
and Brenton (1999) argue that foreign competition from developing countries accounts for a larger share of UK wage inequality than total foreign competition, i.e. import penetration from developing countries offers a more precise indication of the extent to which unskilled workers compete with unskilled labour in low-wage countries. Indeed, the share of imports from developing countries over total imports increased from $18 \%$ to $22 \%$ over the period 1982-1996 indicating an increasing exposure to low-wage competition. As one would expect the impact of all three measures of foreign competition on wage inequality is positive and statistically significant. The coefficients indicate that increased competition from developing countries has indeed a stronger impact on wage inequality than foreign competition from developed countries.

In regressions (5)-(8) several measures of outsourcing are evaluated. In addition to narrow outsourcing 'differential outsourcing' is used, which is defined as the difference between broad and narrow outsourcing. The results indicate that when both measures are included separately both have a positive and significant effect on wage inequality, although the impact of narrow outsourcing is much stronger. However, only narrow outsourcing is positive and significant when both measures are included simultaneously. This result should not come as a surprise. Narrow outsourcing affects the relative demand for labour within that industry, whereas differential outsourcing affects the relative demand for labour everywhere except in its own industry. Differential outsourcing most likely represents the shift from domestic suppliers in another industry to foreign suppliers in that industry. Results in column (7) indicate that an increase of 5 points in the level of outsourcing (close to the actual increase) increases the skilled cost share by approximately 1.55 points compared to an actual increase of 3 points. Outsourcing thus accounted for about half of the increase in skilled cost share over the period 1982-1998 which corresponds to the results found by Feenstra and Hanson (1996). Adjusting outsourcing for the importance of trade with developing countries yields a similar pattern. It is not obvious however whether adjusting outsourcing should be considered an improvement to the unadjusted measure as trade is classified on a product basis instead of on the basis of purchasing industry. In the remainder the unadjusted measure for outsourcing will be used.

Table 3 represents the results with the semi-skilled cost share and the unskilled cost share as the dependent variable instead of the skilled cost share. The regression with the unskilled cost share mirrors the results for the skilled cost share; all variables are negative and significant (except for differential outsourcing that is still insignificant). The results obtained with the semi-skilled cost share as the dependent variable generally gives insignificant results (as could be expected). However, one result is worth discussing. The role of outsourcing seems to differ between both regressions. For unskilled labour narrow outsourcing reduces the relative wage of unskilled workers, whereas for semi-skilled labour differential outsourcing is negative and significant while narrow outsourcing is insignificant.

\section{[Table 3 here]}

If labour markets are not flexible adjustment may be through employment rather than wages. Replacing cost shares by the employment shares gives a similar picture as shown by the results presented in Table 4 . There does no longer seem to be a strong case for excluding relative wages from the regression. Including relative wages does 
not affect the results importantly. Output, $R \& D$ and relative wages are significant and positive. The trade variables are still positive, but insignificant. Capital-intensity turns out insignificant when relative wages are included. Narrow outsourcing is positive and significant and differential outsourcing is insignificant as before.

\section{[Table 4 here]}

\section{Conclusion}

In this paper fragmentation is related to the debate on trade and wages. It is argued that both the sector and the factor bias of outsourcing are likely to affect relative wages. This study focuses on the factor bias by estimating the relative demand for labour derived from the translog cost function using UK data for the period 19821997. Different measures of outsourcing are constructed on the basis of the importuse matrices of the input-output tables. Labour market data are obtained from the New Earnings Survey (NES). This dataset allows one to define skill groups on the basis of the Standard Occupational Classification (SOC) instead of using the crude distinction between manual and non-manual workers used elsewhere in the literature.

The following results are obtained. First, estimations generally indicate a positive relationship between capital intensity and skill intensity confirming the idea that capital and skilled labour are complements. Second, R\&D seems to be appropriate indicators of SBTC. According to the results, an increase in SBTC is associated with an increase in wage inequality. Third, the results indicate a positive and significant effect of foreign competition on wage inequality.

The regressions provide strong evidence of a positive relationship between outsourcing and wage inequality in the UK. Outsourcing could account for as much as half the increase in domestic wage inequality over the period 1982-1997. Typically outsourcing within the same industry is positive and significant whereas outsourcing outside its own industry is generally insignificant. This result should not come as a surprise. Narrow outsourcing affects the relative demand for labour within that industry, whereas differential outsourcing affects the relative demand for labour everywhere except in its own industry. Differential outsourcing most likely represents the shift from domestic suppliers in another industry to foreign suppliers in that industry. Adjusting the outsourcing measure for the importance of trade with developing yields similar results.

Future research will be directed towards improving the understanding of the role of factor bias. Ideally, one would like to analyse the factor and sector bias of technology, trade and outsourcing in a common general equilibrium framework. 


\section{Tables and Figures}

Table 1: Relative Wage Developments UK Manufacturing (1982-1997)

\begin{tabular}{ccccccccccccccccc}
\hline year & 82 & 83 & 84 & 85 & 86 & 87 & 88 & 89 & 90 & 91 & 92 & 93 & 94 & 95 & 96 & 97 \\
\hline $\begin{array}{c}\text { skilled/ } \\
\text { unskilled }\end{array}$ & 1.49 & 1.49 & 1.52 & 1.51 & 1.60 & 1.61 & 1.68 & 1.68 & 1.72 & 1.73 & 1.77 & 1.78 & 1.78 & 1.69 & 1.66 & 1.69 \\
$\begin{array}{c}\text { skilled/ } \\
\text { semi- } \\
\text { skilled } \\
\text { semi- } \\
\text { skilled/ }\end{array}$ & 1.38 & 1.40 & 1.41 & 1.40 & 1.47 & 1.49 & 1.50 & 1.50 & 1.58 & 1.58 & 1.61 & 1.61 & 1.63 & 1.54 & 1.52 & 1.53 \\
unskilled & 1.08 & 1.06 & 1.07 & 1.08 & 1.09 & 1.09 & 1.12 & 1.12 & 1.09 & 1.10 & 1.10 & 1.10 & 1.09 & 1.10 & 1.09 & 1.10 \\
\hline
\end{tabular}

Source: NES, own calculations

Figure 1a:

Cost share of skilled labour

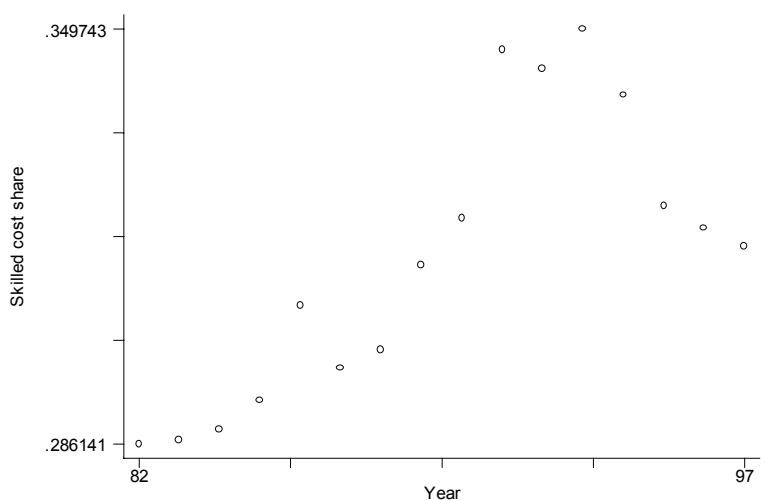

Figure 1b:

Employment share of skilled labour

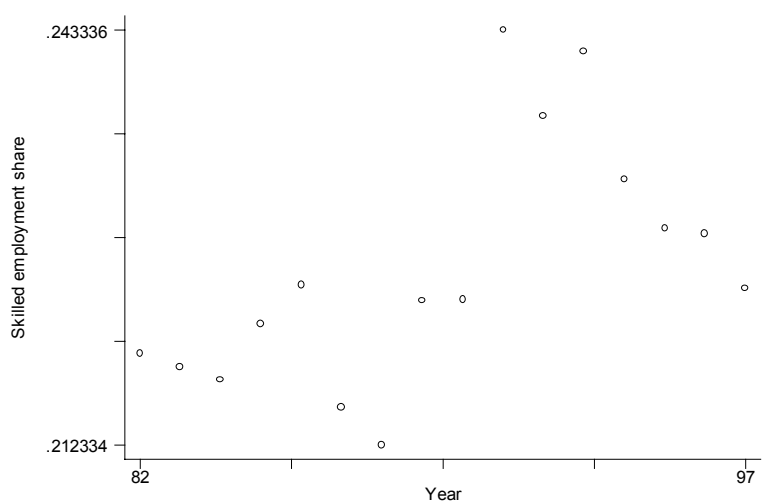

Figure 2: Outsourcing and Skill Intensity (1984-1995)
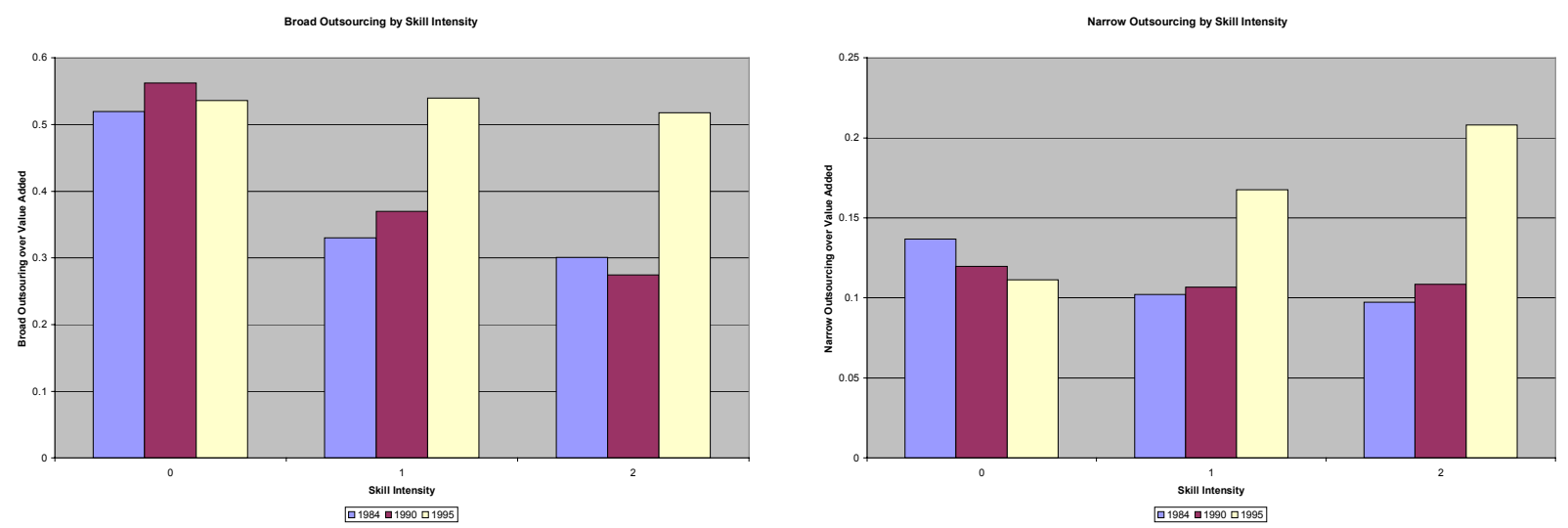

Notes: Clusters are based on the average skill-intensity of industries over the period 1992-1997. Industries in cluster 0 spend on average less than $25 \%$ of the total wage bill on skilled labour, industries in cluster 1 between $25 \%-50 \%$, and industries in cluster 2 spend more than $50 \%$ of the total wage bill on skilled labour. 
Table 2: Skilled cost shares by two-way fixed effects (1982-1997)

\begin{tabular}{|c|c|c|c|c|c|c|c|c|}
\hline & (1) & (2) & (3) & (4) & $(5)$ & $(6)$ & $(7)$ & $(8)$ \\
\hline $\log (\mathrm{K} / \mathrm{Y})$ & $\begin{array}{c}.054 \\
(.023) \\
* *\end{array}$ & $\begin{array}{c}.041 \\
(.024) \\
*\end{array}$ & $\begin{array}{c}.053 \\
(.023) \\
* *\end{array}$ & $\begin{array}{l}.038 \\
(.024)\end{array}$ & $\begin{array}{c}.058 \\
(.023) \\
* *\end{array}$ & $\begin{array}{c}.059 \\
(.023) \\
* *\end{array}$ & $\begin{array}{c}.060 \\
(.023) \\
* * *\end{array}$ & $\begin{array}{c}.059 \\
(.023) \\
* *\end{array}$ \\
\hline $\log (Y)$ & $\begin{array}{c}.155 \\
(.022) \\
* * *\end{array}$ & $\begin{array}{c}.172 \\
(.023) \\
* * *\end{array}$ & $\begin{array}{c}.166 \\
(.023) \\
* * *\end{array}$ & $\begin{array}{c}.168 \\
(.023) \\
* * *\end{array}$ & $\begin{array}{c}.165 \\
(.022) \\
* * *\end{array}$ & $\begin{array}{c}.163 \\
(.022) \\
* * *\end{array}$ & $\begin{array}{c}.168 \\
(.022) \\
* * *\end{array}$ & $\begin{array}{c}.167 \\
(.023) \\
* * *\end{array}$ \\
\hline$R \& D$ & $\begin{array}{c}.066 \\
(.021) \\
* * *\end{array}$ & $\begin{array}{c}.072 \\
(.022) \\
* * *\end{array}$ & $\begin{array}{c}.068 \\
(.022) \\
* * *\end{array}$ & $\begin{array}{c}.071 \\
(.022) \\
* * *\end{array}$ & $\begin{array}{c}.066 \\
(.021) \\
* * *\end{array}$ & $\begin{array}{c}.065 \\
(.021) \\
* * *\end{array}$ & $\begin{array}{c}.065 \\
(.021) \\
* * *\end{array}$ & $\begin{array}{c}.062 \\
(.021) \\
* * *\end{array}$ \\
\hline M1 & & $\begin{array}{c}.025 \\
(.009) \\
* * *\end{array}$ & & & & & & \\
\hline M2 & & & $\begin{array}{c}.038 \\
(.021) \\
*\end{array}$ & & & & & \\
\hline M3 & & & & $\begin{array}{c}.034 \\
(.012) \\
* * *\end{array}$ & & & & \\
\hline $\begin{array}{l}\text { Outsourcing } \\
\text { (Narrow) }\end{array}$ & & & & & $\begin{array}{c}.382 \\
(.070) \\
* * *\end{array}$ & & $\begin{array}{c}.349 \\
(.075) \\
* * *\end{array}$ & \\
\hline $\begin{array}{l}\text { Outsourcing } \\
\text { (Difference) }\end{array}$ & & & & & & $\begin{array}{c}.086 \\
(.028) \\
* * *\end{array}$ & $\begin{array}{c}.037 \\
(.030)\end{array}$ & \\
\hline $\begin{array}{l}\text { Outsourcing } \\
\text { (Narrow } \\
\left.* \mathrm{M}_{\mathrm{ldc}} / \mathrm{M}_{\mathrm{tot}}\right) \\
\text { Outsourcing } \\
\text { (Difference } \\
\left.* \mathrm{M}_{\mathrm{ldc}} / \mathrm{M}_{\mathrm{tot}}\right)\end{array}$ & & & & & & & & $\begin{array}{c}.555 \\
(.180) \\
* * * \\
-.027 \\
(.061)\end{array}$ \\
\hline Constant & $\begin{array}{c}-.304 \\
(.102) \\
* * *\end{array}$ & $\begin{array}{c}-.438 \\
(.106) \\
* * *\end{array}$ & $\begin{array}{c}-.383 \\
(.103) \\
* * *\end{array}$ & $\begin{array}{c}-.466 \\
(.105) \\
* * *\end{array}$ & $\begin{array}{c}-.411 \\
(.102) \\
* * *\end{array}$ & $\begin{array}{c}-.373 \\
(.104) \\
* * *\end{array}$ & $\begin{array}{c}-.432 \\
(.104) \\
* * *\end{array}$ & $\begin{array}{c}-.381 \\
(.099) \\
* * *\end{array}$ \\
\hline R-sq & 0.704 & 0.703 & 0.706 & 0.701 & 0.707 & 0.701 & 0.706 & 0.718 \\
\hline $\mathrm{n}$ & 787 & 781 & 780 & 780 & 787 & 787 & 787 & 780 \\
\hline
\end{tabular}

Notes: Standard error in parentheses, $*, * *, * * *$ indicate significance levels of $10 \%, 5 \%$, and $1 \%$ respectively. Regressions are weighted by the proportion of average sector value added of average manufacturing value added. Imports are divided by 1000. 
Table 3: Unskilled and semi-skilled cost shares by two-way fixed effects (1982-1997)

\begin{tabular}{|c|c|c|}
\hline & $\begin{array}{l}\text { Unskilled cost } \\
\text { share }\end{array}$ & $\begin{array}{l}\text { Semi-skilled } \\
\text { cost share }\end{array}$ \\
\hline $\log (\mathrm{K} / \mathrm{Y})$ & $\begin{array}{c}-.043 \\
(.024) \\
*\end{array}$ & $\begin{array}{l}-.017 \\
(.026)\end{array}$ \\
\hline $\log (Y)$ & $\begin{array}{c}-.106 \\
(.023) \\
* * *\end{array}$ & $\begin{array}{c}-.062 \\
(.025) \\
* *\end{array}$ \\
\hline$R \& D$ & $\begin{array}{c}-.068 \\
(.022) \\
* * *\end{array}$ & $\begin{array}{l}.003 \\
(.023)\end{array}$ \\
\hline $\begin{array}{l}\text { Outsourcing } \\
\text { (Narrow) }\end{array}$ & $\begin{array}{c}-.318 \\
(.078) \\
* * *\end{array}$ & $\begin{array}{l}-.031 \\
(.084)\end{array}$ \\
\hline $\begin{array}{l}\text { Outsourcing } \\
\text { (Difference) }\end{array}$ & $\begin{array}{c}.076 \\
(.031) \\
* *\end{array}$ & $\begin{array}{c}-.113 \\
(.033) \\
* * *\end{array}$ \\
\hline Constant & $\begin{array}{c}.804 \\
(.108) \\
* * *\end{array}$ & $\begin{array}{c}.661 \\
(.116) \\
* * *\end{array}$ \\
\hline R-sq & 0.548 & 0.821 \\
\hline $\mathrm{n}$ & 787 & 787 \\
\hline
\end{tabular}

Table 4: Skilled employment shares by twoway fixed effects (1982-1997)

(1) (2)

\begin{tabular}{lcc}
\hline $\log (\mathrm{K} / \mathrm{Y})$ & .034 & .018 \\
& $(.022)$ & $(.022)$ \\
$\log (\mathrm{Y})$ & .101 & .066 \\
& $(.021)$ & $(.022)$ \\
& $* * *$ & $* * *$ \\
$\mathrm{R} \& \mathrm{D}$ & .046 & .042 \\
& $(.020)$ & $(.019)$ \\
& $* *$ & $* *$ \\
$\mathrm{~W}_{\mathrm{s}} / \mathrm{W}_{\mathrm{u}}$ & & .082 \\
& & $.018)$ \\
& & $* * *$ \\
Outsourcing & .228 & .176 \\
(Narrow) & $(.071)$ & $(.070)$ \\
& $* * *$ & $* *$ \\
Outsourcing & .011 & -.005 \\
(Difference) & $(.028)$ & $(.028)$ \\
& & -.167 \\
Constant & -.174 & $(.091)$ \\
& $(.091)$ & $*$ \\
R-sq & $*$ & 0.627 \\
$\mathrm{n}$ & 0.614 & 789
\end{tabular}

Notes: Standard error in parentheses, ${ }^{*}, * *, * * *$ indicate significance levels of $10 \%, 5 \%$, and 1\% respectively. Regressions are weighted by the proportion of average sector value added of average manufacturing value added. 


\section{References}

Anderton, B. and P. Brenton, "Outsourcing and Low-Skilled Workers in the UK", Bulletin of Economic Research, Vol. 51, No. 4, pp. 267-285.

Arndt, S.W. (1997), "Globalization and the Open Economy", North American Journal of American Economics and Finance, Vol. 8, No. 1, pp. 71-79.

Autor, D.H., L.F. Katz and A.B. Krueger (1998), "Computing Inequality: Have Computers Changed the Labor Market?”, Quarterly Journal of Economics, Vol. 113, pp. 1169-1213.

Baldone, S, F. Sdogati, and L. Tajoli (2001), "Patterns and Determinants of International Fragmentation of Production: Evidence from Outward Processing Trade between the EU and Central and Eastern European Countries", Weltwirtschaftlisches Archiv, Vol. 137, No.1, pp. 80-104.

Baldwin, R.E. and G.G. Cain (2000), "Shifts in Relative U.S. Wages: The Role of Trade, Technology, and Factor Endowments", Review of Economics and Statistics, Vol. 82, pp. 580-595.

Berman, E., J. Bound, and Z. Griliches (1994), "Changes in the Demand for Skilled Labor within U.S. Manufacturing: Evidence from the Annual Survey of Manufacturers", Quarterly Journal of Economics, Vol. 109, pp. 367-397.

Campa, J. and L.S. Goldberg (1997), "The Evolving External Orientation of Manufacturing Industries: Evidence from four Countries", NBER Working Paper, No. 5919.

Chennels, L. and J. Van Reenen (1999), "Has Technology Hurt Less Skilled Workers? An Econometric Survey of the Effects of Technical Change on the Structure of Pay and Jobs", The Institute for Fiscal Studies, Working Paper Series No. W99/27.

Corbett \& Associates (1999), "Ten Years of Outsourcing Practice: Tactical, Strategic and Tranfomational", CIO Magazine.

Dell'mour, R., P. Egger, K. Gugler, M. Pfaffermayr (2000), “Outsourcing of Austrian Manufacturing to Eastern European Countries: Effects on Productivity and the Labor Market", in Arndt, S., H. Handler and D. Salvatore (ed.), Fragmentation of the Value Added Chain, Austrian Ministry for Economic Affairs and Labour, Vienna.

Egger, H. and P. Egger (2001), "Cross-border sourcing and outward processing in EU manufacturing", North American Journal of Economics and Finance, Vol. 12, pp. 243-256.

Feenstra, R.C (1998), 'Integration of Trade and Disintegration of production in the Global Economy, Journal of Economic Perspectives, Fall 1998, pp. 31-50. 
Feenstra, R.C. and G.H. Hanson (1995), "Foreign Investment, Outsourcing, and Relative Wages", NBER Working Paper 5121.

Feenstra, R.C. and G.H. Hanson (1996), "Globalization, Outsourcing, and Wage Inequality", American Economic Review, Vol. 86, Iss. 2, pp. 240-245.

Feenstra, R.C. and G.H. Hanson (1999), "The Impact of Outsourcing and HighTechnology Capital on Wages: Estimates for the United States, 1979-1990”, Quarterly Journal of Economics, Vol. 114, Iss. 3, pp. 907-941.

Feenstra, R.C. and G.H. Hanson (2001), "Global Production Sharing and Rising Wage Inequality”, NBER Working Paper, No. 8372.

Gregory, M., B. Zissimos, and C. Greenhalgh (2001), 'Jobs for the skilled: how technology, trade, and domestic demand changed the structure of UK employment, 1979-1990', Oxford Economic Papers, Vol. 53, No. 1, pp. 20-41.

Griliches, Z. and J. Hausman (1986), "Errors in Variables in Panel Data", Journal of Econometrics, Vol. 31, pp. 93-118.

Görg, H. (2000), 'Fragmentation and Trade: US Inward Processing Trade in the EU', Weltwirtschaftliches Archiv, Vol. 136(3), pp. 403-421.

Haskel, J.E. (2000), "Trade and Labour Approaches to Wage Inequality", Review of International Economics, Vol. 8, No. 3, pp. 397-408.

Haskel, J.E. and Y. Heden (1999), "Computers and the Demand for Skilled Labour: Industry- and Establishment-level Panel Evidence for the UK", Economic Journal, Vol. 109, No. 454, pp. 68-79.

Haskel and Slaughter (2001), "Trade, Technology, and UK Wage Inequality", Economic Journal, Vol. 111, pp. 163-187.

Hijzen (2002), "Fragmentation, Productivity, and Relative Wages in the UK: A General Equilibrium Approach", University of Nottingham, mimeo.

Hummels, D., J. Ishii, and K. Yi (2001), "The Nature and Growth of Vertical Specialisation in World Trade", Journal of International Economics, Vol. 54, pp. 7596.

Jones, R.W. and H. Kierzkowski (1990), "The Role of Services in Production and International Trade: A Theoretical Framework", in R.W. Jones and A. Krueger (eds.), The Political Economy of International Trade, Oxford, Basil Blackwell.

Jones, R.W. and H. Kierzkowski (2001), "A Framework for Fragmentation”, in S.W. Arndt, and H. Kierzkowski, Fragmentation: New Production Patterns in the World Economy, Oxford University Press.

Kohler, W. (2001), "A specific-factors view on outsourcing", North American Journal of Economics and Finance, Vol. 12, pp. 31-53. 
Krugman, P.R. (2000), "Technology, Trade and Factor Prices", Journal of International Economics, Vol. 50, pp. 51-71.

Leamer, E.E. (1998), "In Search of Stolper-Samuelson Linkages between International Trade and Lower Wages", in S.M. Collins (eds.), Imports, Exports, and the American Worker, Washington D.C., Brookings Institution Press, pp. 143-203.

Machin, S. and J. van Reenen (1998), "Technology and Changes in Skill Structure: Evidence form Seven OECD Countries", Quarterly Journal of Economics, November, pp. 1215-1244.

Ng, F. and A. Yeats (1999), "Production Sharing in East Asia: Who Does What for Whom and Why?", World Bank Working Paper No. 2197.

Slaughter, M. (1999), 'Globalisation and Wages: A Tale of Two Perspectives', The World Economy, Vol. 22, pp. 609-630.

Slaughter, M. (2000), "What are the Results of Product-Price Studies and What Can We Learn form their Differences" in R.C. Feenstra (ed.), The Impact of International Trade on Wages, The University of Chicago Press.

Yeats, A.J. (1998), “Just How Big is Global Production Sharing?", in S.W. Arndt, and H. Kierzkowski, Fragmentation: New Production Patterns in the World Economy, Oxford University Press. 


\section{Appendix I: Data}

Data on sales, value added and capital expenditure are obtained from the Census of Production. Capital stock data are estimated from capital expenditures using the Perpetual Inventory Method (PIM). At least two difficulties arise when estimating the capital stock. First, economic depreciation consists of two elements: physical deterioration due to usage or ageing, and obsolence, which refers to the reduction of efficiency relative to new assets. Second, different types of capital are subject to different rates of depreciation. Oulton and O'Mahony (1994) provide estimates for the total rate of economic depreciation for five different types of capital. In addition, they present estimates of the proportion of capital expenditure on each capital type for various years over the period 1968-1984 for 10 industries. Combining this information it is possible to generate industry-specific depreciation rates. Applying PIM with a pattern of geometric decay gives the following formula:

$$
K_{i t}=\sum_{t-q}^{t}\left(1-\sum_{1}^{k} S_{k} \delta_{k}\right)^{q-1} I_{i, t-q}+\left(1-\sum_{1}^{k} S_{k} \delta_{k}\right)^{t-1979} K_{i, 1979}
$$

The capital stock for industry $i$ at time $t$ equals the sum of expenditure on asset $k$ at time $t-q$ depreciated by the asset-specific economic depreciation rate $\delta_{k}$ plus the depreciated benchmark capital stock. Both the proportion of capital expenditure on each asset, $S_{k}$, and the depreciation rate are assumed constant over time. This way annual capital stock estimates are generated.

Disaggregated data on expenditure on R\&D are only available for the period 19821990. For the missing years R\&D is extrapolated using sales. Trade data are obtained from the OECD Trade Database. The trade data are classified according to SITC Rev. 2 and Rev.3. The industry data on sales, value added and capital are classified according to $\mathrm{SIC}(80)$ and $\mathrm{SIC}(92)$ respectively. Based on product descriptions and industry size a 'best guess' for each SIC(92) industry was obtained. Consequently, industries were regrouped in order to make the classification compatible to the level of aggregation in the I-O tables. The correspondence table thus obtained distinguished 53 SIC manufacturing industries. The table should be fairly reliable in both ways. ${ }^{21}$

The outsourcing variable is constructed using the following procedure. The data on imported intermediate purchases are available for the following three years: 1984, 1990, and 1995. Annual data on total intermediate purchases (domestic and imported) are available for the period 1992-1997. Imported intermediate purchases are therefore extrapolated using total intermediate purchasing where possible. The remaining gaps are filled up with linear extrapolation.

\footnotetext{
${ }^{21}$ The most detailed mapping publicly made available by the CSO, allows just a maximum of 28 industries. This clearly shows that there is a cost of having a larger sample size (Gregory et al., 2001). The concordance table between SIC80 and SIC92 used here is based on work by Vishal Ragoobur. Vishal Ragoobur also kindly provided the correspondence between SITC Rev.2 and SIC80, while the correspondence between SITC Rev. 3 and SIC80 was provided by Vicente Blanes and Rob Elliot.
} 


\section{Appendix II: Standard Occupational Classification}

\section{$\underline{\text { Major Groups }}$}

1 Managers and Administrators

2 Professional Occupations

3 Associate Professional and Technical Occupations

4 Clerical and Secretarial Occupations

5 Craft and Related Occupations

6 Personal and Protective Service Occupations

7 Sales Occupations

8 Plant and Machine Occupations

9 Other Occupations

\section{$\underline{\text { Sub-Major Groups }}$}

1 Corporate Managers and Administrators

2 Managers/Proprietors in Agriculture and Services

3 Science and Engineering Professionals

4 Health Professionals

5 Teaching Professionals

6 Other Professional Occupations

7 Science and Engineering Associate Professionals

8 Health Associate Professionals

9 Other Associate Professional Occupations

10 Clerical Occupations

11 Secretarial Occupations

12 Skilled Construction Trades

13 Skilled Engineering Trades

14 Other Skilled Trades

15 Protective Service Occupations

16 Personal Service Occupations

17 Buyers, Brokers and Sales Reps.

18 Other Sales Occupations

19 Industrial Plants and Machine Operators, Assemblers

20 Drivers and Mobile Machine Operators

21 Other Occupations in Agriculture, Forestry and Fishing

22 Other Elementary Occupations 


\section{IZA Discussion Papers}

\begin{tabular}{|c|c|c|c|c|}
\hline No. & Author(s) & Title & Area & Date \\
\hline 702 & $\begin{array}{l}\text { M. Ayhan Kose } \\
\text { E. S. Prasad } \\
\text { M. E. Terrones }\end{array}$ & $\begin{array}{l}\text { How Does Globalization Affect the } \\
\text { Synchronization of Business Cycles? }\end{array}$ & 2 & $01 / 03$ \\
\hline 703 & $\begin{array}{l}\text { W. C. Horrace } \\
\text { R. L. Oaxaca }\end{array}$ & $\begin{array}{l}\text { New Wine in Old Bottles: A Sequential } \\
\text { Estimation Technique for the LPM }\end{array}$ & 6 & $01 / 03$ \\
\hline 704 & $\begin{array}{l}\text { M. Ransom } \\
\text { R. L. Oaxaca }\end{array}$ & Intrafirm Mobility and Sex Differences in Pay & 1 & $01 / 03$ \\
\hline 705 & $\begin{array}{l}\text { G. Brunello } \\
\text { D. Checchi }\end{array}$ & School Quality and Family Background in Italy & 2 & $01 / 03$ \\
\hline 706 & $\begin{array}{l}\text { S. Girma } \\
\text { H. Görg }\end{array}$ & $\begin{array}{l}\text { Blessing or Curse? Domestic Plants' Survival } \\
\text { and Employment Prospects after Foreign } \\
\text { Acquisitions }\end{array}$ & 1 & $01 / 03$ \\
\hline 707 & $\begin{array}{l}\text { C. Schnabel } \\
\text { J. Wagner }\end{array}$ & $\begin{array}{l}\text { Trade Union Membership in Eastern and } \\
\text { Western Germany: Convergence or } \\
\text { Divergence? }\end{array}$ & 3 & $01 / 03$ \\
\hline 708 & $\begin{array}{l}\text { C. Schnabel } \\
\text { J. Wagner }\end{array}$ & $\begin{array}{l}\text { Determinants of Trade Union Membership in } \\
\text { Western Germany: Evidence from Micro Data, } \\
\text { 1980-2000 }\end{array}$ & 3 & $01 / 03$ \\
\hline 709 & $\begin{array}{l}\text { L. Danziger } \\
\text { S. Neuman }\end{array}$ & $\begin{array}{l}\text { Delays in Renewal of Labor Contracts: Theory } \\
\text { and Evidence }\end{array}$ & 1 & $02 / 03$ \\
\hline 710 & $\begin{array}{l}\text { Z. Eckstein } \\
\text { Y. Weiss }\end{array}$ & $\begin{array}{l}\text { On the Wage Growth of Immigrants: Israel, } \\
1990-2000\end{array}$ & 2 & $02 / 03$ \\
\hline 711 & C. Ruhm & Healthy Living in Hard Times & 3 & $02 / 03$ \\
\hline 712 & $\begin{array}{l}\text { E. Fehr } \\
\text { J. Henrich }\end{array}$ & $\begin{array}{l}\text { Is Strong Reciprocity a Maladaptation? On the } \\
\text { Evolutionary Foundations of Human Altruism }\end{array}$ & 5 & $02 / 03$ \\
\hline 713 & $\begin{array}{l}\text { I. Gang } \\
\text { J. Landon-Lane } \\
\text { M. S. Yun }\end{array}$ & $\begin{array}{l}\text { Does the Glass Ceiling Exist? A Cross-National } \\
\text { Perspective on Gender Income Mobility }\end{array}$ & 2 & $02 / 03$ \\
\hline 714 & M. Fertig & $\begin{array}{l}\text { Educational Production, Endogenous Peer } \\
\text { Group Formation and Class Composition - } \\
\text { Evidence From the PISA } 2000 \text { Study }\end{array}$ & 6 & $02 / 03$ \\
\hline 715 & $\begin{array}{l}\text { E. Fehr } \\
\text { U. Fischbacher } \\
\text { B. von Rosenbladt } \\
\text { J. Schupp } \\
\text { G. G. Wagner }\end{array}$ & $\begin{array}{l}\text { A Nation-Wide Laboratory Examining Trust and } \\
\text { Trustworthiness by Integrating Behavioral } \\
\text { Experiments into Representative Surveys }\end{array}$ & 7 & $02 / 03$ \\
\hline 716 & $\begin{array}{l}\text { M. Rosholm } \\
\text { L. Skipper }\end{array}$ & $\begin{array}{l}\text { Is Labour Market Training a Curse for the } \\
\text { Unemployed? Evidence from a Social } \\
\text { Experiment }\end{array}$ & 6 & $02 / 03$ \\
\hline 717 & $\begin{array}{l}\text { A. Hijzen } \\
\text { H. Görg } \\
\text { R. C. Hine }\end{array}$ & $\begin{array}{l}\text { International Fragmentation and Relative Wages } \\
\text { in the UK }\end{array}$ & 2 & $02 / 03$ \\
\hline
\end{tabular}

An updated list of IZA Discussion Papers is available on the center's homepage www.iza.org. 